\title{
Alternative Organic Fungicides for Apple Scab Management and Their Non-target Effects
}

\author{
Morgan L. Cromwell ${ }^{1}$, Lorraine P. Berkett, and Heather M. Darby \\ Department of Plant and Soil Science, University of Vermont, 63 Carrigan \\ Drive, Jeffords Building, Burlington, VT 05405
}

Takamaru Ashikaga

Medical Biostatistics, University of Vermont, Burlington, VT 05405

Additional index words. apple, organic production, alternative fungicides, non-target effects, apple scab (Venturia inaequalis)

\begin{abstract}
A major challenge in organic apple production in humid production regions is the available fungicide options for apple scab [Venturia inaequalis (Cooke) Wint.] management. The standard sulfur/lime sulfur fungicide program can be injurious to the applicator, the apple ecosystem, and the apple tree itself. The objectives of this study were to compare the efficacy of three potential alternative fungicides [potassium bicarbonate (PB), neem oil (NO), and Bacillus subtilis (Bs)] with a standard organic sulfur/lime sulfur (SLS) fungicide program and a non-treated control (NTC) for management of apple scab and to evaluate potential non-target impacts on pest and beneficial arthropod populations. The five treatments were applied to 'Empire' trees arranged in a completely randomized design with five single-tree replications at the University of Vermont Horticultural Research Center in South Burlington, VT. Fungicides were applied with a handgun to drip using maximum label rates. Applications began on 26 Apr. 2007 and 23 Apr. 2008 and continued on approximately a weekly schedule through the end of June and then every 2 weeks through 23 July 2007 and 17 July 2008, respectively. The standard SLS treatment resulted in the best scab control in both years. The NO treatment reduced foliar and fruit scab compared with the NTC and the other alternatives at the end of the $\mathbf{2 0 0 8}$ growing season and had insecticidal activity. However, both the SLS and NO treatments had disadvantages, including phytotoxic burning on the fruit and/or significantly more russeting on the fruit at harvest. In each year of the study, one or more of the alternative treatments, particularly Bs, resulted in higher insect damage than the non-fungicide-treated control. This research showed that PB, Bs, and NO do not offer advantages over the standard SLS fungicide program in organic apple production and in some cases offer distinct disadvantages in terms of non-target impacts. Chemical names used: potassium bicarbonate (Armicarb “O”), Bacillus subtilis (Serenade MAX), neem oil (Trilogy), sulfur (Microthiol Sulfur)/lime sulfur (Miller Lime Sulfur)
\end{abstract}

A major limitation to organic apple [Malus sylvestris (L.) Mill. var. domestica (Borkh.) Mansf.] production is the available fungicide options for apple scab, a significant disease of apples in humid production regions. Apple scab can have devastating impacts, including a decrease in fruit quality and yield (Cooley et al., 2008; MacHardy, 1996). Fruit infection causes deformities, cracks, and fruit drop. Severe foliar infection can lead to premature defoliation and reduced tree vigor, which in turn may restrict or prevent formation of fruit buds for the next year (Jones and Aldwinckle, 1990).

\footnotetext{
Received for publication 4 Apr. 2011. Accepted for publication 25 June 2011.

This research was funded, in part, by a grant from the USDA Integrated Organic Program.

We thank Terence Bradshaw for his endless help in the field and Sarah Kingsley-Richards for all those long tedious days of data collection.

${ }^{1}$ To whom reprint requests should be addressed; e-mailmorgan.cromwell@uvm.edu.
}

Of the fungicides approved for use under organic apple certification standards such as those recommended by the Organic Materials Review Institute, only sulfur or lime sulfur is commonly used against Venturia inaequalis in organic apple production in New England (Cooley et al., 2008). Liquid lime sulfur (calcium polysulfide, made by reacting calcium hydroxide with sulfur) was a highly recommended fungicide in the early 20th century, was effective as a protectant fungicide, and could also be used to eradicate established infections (Hamilton and Keitt, 1928). However, lime sulfur-based fungicides are highly caustic and can be injurious to the tree, lowering photosynthesis rates, and reducing fruit set and pollen germination (Burrell, 1945; Environmental Protection Agency, 2006; MacDaniels and Furr, 1930; MacHardy, 1996; McArtney et al., 2006; Palmer et al., 2003). Lime sulfur applications can also result in lower fruit yields, premature fruit drop, and can cause russeting and phytotoxic burns on the fruit, lowering fruit quality (Burrell, 1945; Holb et al., 2003; MacHardy, 1996; Palmiter and Smock, 1954). Elemental sulfur materials are less caustic to the applicator and consequently, wettable elemental sulfur fungicides have been incorporated into programs with lime sulfur (MacHardy, 1996). However, elemental sulfur fungicides are considered less effective with only weak protective activity against apple scab (Cooley et al., 2008; Ellis et al., 1998; Lewis and Hickey, 1972). Both elemental sulfur and lime sulfur fungicides have adverse, non-target effects on beneficial predatory mites (Holdsworth, 1972; MacPhee and Sanford, 1954, 1956; van de Vrie, 1962).

Because of the negative attributes of the standard sulfur/lime sulfur fungicides in organic apple production, it is important to evaluate the effectiveness of alternative, organically approved fungicides. Potassium bicarbonate (Eco-Mate Armicarb "O”; Helena Chemical Co., Collierville, TN; 85\% a.i.), Bacillus subtilis strain QST713 (Serenade MAX; AgraQuest, Davis, CA; $14.6 \%$ a.i.), and clarified hydrophobic extract of neem oil (Trilogy; Certis U.S.A. L.LC., Columbia, MD; 70\% a.i.) are fungicides that were approved for organic apple production but have not been fully evaluated and compared with the standard sulfur/lime sulfur fungicide program in the humid production region of New England. Potassium bicarbonate has been shown to have activity against apple scab and sooty blotch (an extensive complex of fungi as documented by Díaz Arias et al., 2010) in Switzerland apple orchards (Tamm et al., 2006). A potassium bicarbonate treatment on multiple cultivars in field experiments in Romania resulted in significantly reduced foliar and fruit apple scab (Mitre et al., 2009, 2010). The Armicarb formulation of potassium bicarbonate significantly reduced apple scab severity on leaves and fruit compared with a water control treatment and was as effective as an elemental sulfur treatment in field trials in Belgium (Jamar et al., 2008, 2010). Past research evaluating Bacillus subtilis on apple trees in Pennsylvania showed that trees treated with Serenade MAX had significantly lower apple scab incidence and severity than a nontreated water control treatment (Travis et al., 2005). Extracts from the neem tree, Azadirachta indica such as azadirachtin, are commonly used as an insecticide but have shown antifungal properties against postharvest apple diseases [Botrytis cinerea (pers.) ex Fr., Penicillium expansum Thom., and Glomerella cingulata (Ston.) Spauld. \& Schrenk] (Moline and Locke, 1993). These materials were labeled as organically approved fungicides for management of apple scab and other fungal diseases such as cedar apple rust [ Gymnosporangium juniperi-virginianae (Schwein)], fruit rots, sooty blotch, and flyspeck [Zygophiala jamaicensis (E. Mason)].

The major objectives of this research were to: 1) evaluate the efficacy of alternative fungicides (potassium bicarbonate, Bacillus subtilis, and neem oil) against apple scab compared with a standard sulfur and lime sulfur fungicide program; and 2) evaluate the potential nontarget effects of the fungicide treatments on beneficial and pest arthropod populations. 
Portions of the results from the first year of this experiment are published (Cromwell et al., 2008).

\section{Materials and Methods}

The study was conducted at the University of Vermont Horticultural Research Center in South Burlington, VT, on 'Empire' trees on M.7 or Mark rootstocks that averaged $3.0 \mathrm{~m}$ high $\times 3.0 \mathrm{~m}$ wide and were planted in 1990 at a spacing of $3.7 \mathrm{~m} \times 5.5 \mathrm{~m}$. Previous research in this orchard showed that the rootstock did not affect disease incidence and therefore, it was not considered a variable in this experiment (Reardon et al., 2005). Treatments were arranged in a completely randomized design with five single-tree replications of the five treatments: PB, Bs, NO, SLS, and NTC. Before 2007, the experimental orchard was managed using standard integrated pest management practices. The research orchard was not organically certified.

A "scab risk" assessment was conducted for the study in the fall of 2006 and 2007 to determine the potential risk for apple scab in the spring of 2007 and 2008, respectively (Cooley et al., 2008; Reardon et al., 2005). Based on the 2006 "scab risk" assessment, we concluded the orchard was at a "low" risk for apple scab; however, from the 2007 assessment, we determined the orchard was at a "high" risk for scab in Spring 2008. Thus, in the fall of 2007, sanitation measures were undertaken to reduce the amount of overwintering pathogen on fallen scabbed leaves (Cromwell et al., 2009). Sanitation measures were unnecessary in the fall of 2006 because the inoculum level was low, indicated by the "low" risk rating.

Fungicides were applied with a 189-L, three-point hitch PTO sprayer (Nifty Fifty; Rears Mfg. Co., Eugene, OR) with an attached Green Garde handgun (Model JD9-C; Chicago, IL) having an L tip at a pressure of $689 \mathrm{kpa}$. Maximum labeled product rates of the following materials were applied dilute to drip: potassium bicarbonate at $4.2 \mathrm{~kg} \cdot \mathrm{ha}^{-1}$; Bacillus subtilis at $3.4 \mathrm{~kg} \cdot \mathrm{ha}^{-1}$; neem oil at $18.7 \mathrm{~L} \cdot \mathrm{ha}^{-1}$; sulfur at $16.8 \mathrm{~kg} \cdot \mathrm{ha}^{-1}$; and lime sulfur at $18.7 \mathrm{~L} \cdot \mathrm{ha}^{-1}$. Fungicide applications in 2007 began on 26 Apr. and continued on approximately a weekly schedule through the end of June and then every 2 weeks to the last fungicide application on 23 July (Table 1). Applications were made weekly in 2008 from 23 Apr. through the end of June and every 2 weeks until 17 July (Table 1). Conditions were highly conducive for fire blight [Erwinia amylovora (Burrill) Winslow et al.] in 2007, so streptomycin sulfate (Agri-Mycin 17; Nufarm Americas, Inc. Burr Ridge, IL) was applied at $1.1 \mathrm{~kg} \cdot \mathrm{ha}^{-1}$ on 11 May 2007 using a Rears Pak-Blast 100 sprayer (Rears Manufacturing, Eugene, OR). To suppress fire blight in 2008, copper (C-OC-S WDG; Loveland Products, Inc., Greeley, $\mathrm{CO})$ at $6.7 \mathrm{~kg} \cdot \mathrm{ha}^{-1}$ was applied to all experimental trees with the Rears Pak-Blast 100 sprayer at the silver tip phenological stage on 18 Apr. 2008.

Table 1. Apple scab on 'Empire' trees, 2007 and 2008.

\begin{tabular}{|c|c|c|c|c|c|}
\hline & & \multicolumn{4}{|c|}{ Scab incidence (percent leaves or fruit affected) } \\
\hline \multicolumn{2}{|c|}{2007} & Cluster leaves $^{\mathrm{x}}$ & \multicolumn{2}{|c|}{ Terminal leaves ${ }^{x}$} & Fruit $^{x}$ \\
\hline Treatment and rate/ha & Application timing $^{2}$ & 18-20 June & 18-20 June & 22-24 Aug. & 10-Sept. \\
\hline PB $4.2 \mathrm{~kg}$ & $1-12$ & $0.1^{\mathrm{w}}$ & 0.4 & $12.3 \mathrm{~b}$ & $11.2 \mathrm{bc}$ \\
\hline Bs $3.4 \mathrm{~kg}$ & $1-12$ & 0.3 & 1.5 & $17.0 \mathrm{~b}$ & $22.4 \mathrm{ab}$ \\
\hline NO $18.7 \mathrm{~L}$ & $1-12$ & 0 & 1.2 & $9.9 \mathrm{~b}$ & $11.6 \mathrm{bc}$ \\
\hline $\mathrm{S} 16.8 \mathrm{~kg}$ & $1,5,8,10-12$ & & & & \\
\hline LS $18.7 \mathrm{~L}$ & $2-4,6-7,9$ & 0 & 0.7 & $1.1 \mathrm{c}$ & $0.4 \mathrm{c}$ \\
\hline NTC & $1-12$ & 0.3 & 2.4 & $29.2 \mathrm{a}$ & $25.2 \mathrm{a}$ \\
\hline
\end{tabular}

Scab incidence (percent leaves or fruit affected)

\begin{tabular}{|c|c|c|c|c|c|}
\hline \multirow{2}{*}{\multicolumn{2}{|c|}{2008}} & & & & \\
\hline & & Cluster leaves $^{\mathrm{x}}$ & \multicolumn{2}{|c|}{ Terminal leaves $^{x}$} & \multirow{2}{*}{$\frac{\text { Fruit }^{\mathrm{x}}}{\text { 3-Sept. }}$} \\
\hline Treatment and rate/ha & Application timing ${ }^{y}$ & 16-18 June & 16-18 June & 12-15 Aug. & \\
\hline$\overline{\mathrm{PB}} 4.2 \mathrm{~kg}$ & $1-12$ & $2.1 \mathrm{c}^{\mathrm{w}}$ & $13.6 \mathrm{~b}$ & $41.5 \mathrm{~b}$ & $45.8 \mathrm{~b}$ \\
\hline Bs $3.4 \mathrm{~kg}$ & $1-12$ & $5.2 \mathrm{bc}$ & $16.9 \mathrm{ab}$ & $54.5 \mathrm{a}$ & $62.4 \mathrm{a}$ \\
\hline NO $18.7 \mathrm{~L}$ & $1-12$ & $7.6 \mathrm{ab}$ & $9.9 \mathrm{bc}$ & $28.7 \mathrm{c}$ & $32.4 \mathrm{c}$ \\
\hline $\mathrm{S} 16.8 \mathrm{~kg}$ & $8-12$ & & & & \\
\hline LS $18.7 \mathrm{~L}$ & $1-7$ & $1.1 \mathrm{c}$ & $4.3 \mathrm{c}$ & $8.9 \mathrm{~d}$ & $2.9 \mathrm{~d}$ \\
\hline NTC & $1-12$ & $10.9 \mathrm{a}$ & $21.9 \mathrm{a}$ & $55.7 \mathrm{a}$ & $64.0 \mathrm{a}$ \\
\hline
\end{tabular}

${ }^{\mathrm{z}}$ Application timings: 1 = (Green tip) 26 Apr.; $2=$ (TC) 7 May; $3=$ (Pink) 11 May; 4 = (Pink) 17 May; $5=$ (Pink-Bloom) 24 May; 6 = (Petal fall) 29 May; $7=7$ June; $8=14$ June; $9=22$ June; $10=29$ June; $11=12$ July; 12 = 23 July.

${ }^{\mathrm{y}}$ Application timings: $1=($ Green tip) 23 Apr.; $2=(\mathrm{TC}) 1$ May; $3=($ Pink $) 7$ May; $4=($ Bloom $) 14$ May; $5=$ (Petal fall) 21 May; $6=30$ May; $7=5$ June; $8=12$ June; $9=19$ June; $10=26$ June; $11=2$ July; $12=17$ July. ${ }^{x}$ Assessment of 10 clusters, 10 terminals, and 50 fruit per tree on five single-tree replicates per treatment. "Numbers within columns followed by the same letter do not differ significantly, Fisher's protected least significant difference, $P \leq 0.05$; columns with no letters following the numbers do not have a significant F-value, analysis of variance, $P \leq 0.05$ or Kruskal-Wallis, $P \leq 0.05$, when data normality could not be rescued with data transformation because of zeros in data.

Weather was monitored with a Davis Vantage Pro Wireless Weather Station (Davis Instruments Corp., Hayward, CA) and primary apple scab infection periods were calculated according to formulas based on the Mills table using the minimum hours of leaf wetness necessary for an infection period (MacHardy and Gadoury, 1989; Reardon et al., 2005; Stensvand et al., 1997), with the exception that wetting periods starting with nightfall rains were also included in the calculations because a portion of ascospores are released at night (Gadoury et al., 1998). Secondary infection periods were determined similarly with the exception that leaf wetness hours caused by dew alone were also included. Ascospore maturity was calculated using the New Hampshire model developed by Gadoury and MacHardy (1982). The potential release of mature ascospores was determined according to criteria established by Gadoury et al. (1998) and used by Reardon et al. (2005).

The 2007 primary scab season had six infection periods spanning $17 \mathrm{~d}: 27$ to 30 Apr.; 10 to 11,15 to 17,19 to 21 , and 27 to 28 May; and 31 May to 2 June. In 2008, there were six primary infection periods covering $13 \mathrm{~d}$ : 28 to 29 Apr.; 2 to $4,15,22$ to 24 , and 26 to 27 May; and 31 May to 1 June. Overall, 2007 had more wet days, days in which an infection period occurred, during the primary season, but there were a total of 55 wet days in the secondary scab season in 2008 , eight more than the 47 wet days that occurred in 2007 (Cromwell et al., 2009).

Insecticides and miticides were applied based on a standard organic management program in 2007. Materials were applied to the whole orchard using a Rears Pak-Blast 100 sprayer. Horticultural oil (JMS Stylet oil;
JMS Flower Farms, Inc., Vero Beach, FL) was applied at the silver tip phenological stage (22 Apr. 2007 at $24.3 \mathrm{~L} \cdot \mathrm{ha}^{-1}$ ) and at the half-inch green tip stage (7 May 2007 at 15.9 $\mathrm{L} \cdot \mathrm{ha}^{-1}$ ) for management of mites [Panonychus ulmi (Koch)]. Bacillus thuringiensis (Dipel DF; Valent USA Corp., Walnut Creek, CA) was applied on 7 and 14 June 2007 and on 2 Aug. 2007 for codling moth [Cydia pomonella (L.)] at $1.1 \mathrm{~kg} \cdot \mathrm{ha}^{-1}$; spinosad (Entrust; Dow AgroSciences, L.L.C., Indianapolis, IN) was used on 29 June 2007 for oblique banded leafroller [Choristoneura rosaceana (Harris)] and on 2 Aug. 2007 for codling moth and apple maggot fly [Rhagoletis pomonella (Walsh)] at $0.1 \mathrm{~L} \cdot \mathrm{ha}^{-1}$. In addition, kaolin clay (Surround WP; Tessenderlo Kerley, Inc., Phoenix, AZ) was applied three times on 29 May at $70.1 \mathrm{~kg} \cdot \mathrm{ha}^{-1}$ and on 14 and 22 June 2007 at $46.8 \mathrm{~kg} \cdot \mathrm{ha}^{-1}$, targeting European apple sawfly [Hoplocampa testudinea (Klug)] and/or plum curculio [Conotrachelus nenuphar (Herbst)]. In 2008, horticultural oil (JMS Stylet oil) was applied at silver tip, 18 Apr. 2008 at $24.3 \mathrm{~L} \cdot \mathrm{ha}^{-1}$, for management of mites. No insecticides, except kaolin clay (Surround WP), were applied in 2008 to better assess any non-target effects of the fungicides on insect populations. Kaolin clay (Surround WP) was applied two times on 22 and 29 May 2008 at $70.1 \mathrm{~kg} \cdot \mathrm{ha}^{-1}$ for European apple sawfly and plum curculio and once more on 5 June 2008 at $46.8 \mathrm{~kg} \cdot \mathrm{ha}^{-1}$ for plum curculio.

Apple scab incidence was assessed by observing presence or absence of symptoms on both sides of all leaves on a representative sample of 10 fruit clusters and 10 vegetative terminals from each single-tree replicate for each of the five treatments on 18 to 20 June 
2007 and 16 to 18 June 2008. In addition, all the fruit on each cluster was assessed for incidence of damage caused by tarnished plant bug [Lygus lineolaris (Palisot de Beauvois)], European apple sawfly, and plum curculio damage.

Disease assessment of vegetative terminals in August followed the same procedures as in June and was completed on 22 to 24 Aug. 2007 and 12 to 15 Aug. 2008, respectively. The presence of foliar phytotoxicity was recorded for each leaf as non-specific, unidentified necrotic leaf spots. In addition, each leaf evaluated for disease was also observed for the presence of and/or damage from the following arthropod pests: spotted tentiform leafminer [Phyllonorycter blancardella (Fabr.)] or apple blotch leafminer [Phyllonorycter crataegella (Clemens)]; lyonetia leafminer [Lyonetia prunifoliella (Hübner)]; green apple aphid (Aphis pomi); European red mite; two-spotted spider mite [Tetranychus urticae (Koch)]; white apple leafhopper [Typhlocyba pomaria (McAtee)]; potato leafhopper [Empoasca fabae (Harris)]; and Japanese beetle [Popillia japonica (Newman)]. The presence/absence incidences were also recorded for beneficial insects such as: lady beetle adults and larvae (Coleoptera: Coccinellidae); cecidomyiid larvae (Diptera: Cecidomyiidae); syrphid fly larvae (Diptera: Syrphidae); and chrysopid eggs (Neuroptera: Chrysopidae).

Because this experiment was initially designed with disease management as a priority, only foliage free of both disease and arthropods were recorded in the first year. However, after initial observations indicated there may be differences among the treatments, foliage free of only arthropods and their damage was recorded separately in the second year of the study. Therefore, leaves with no evidence of pests or pest damage were recorded as free of arthropod damage during assessments in 2008 to see overall insecticidal activity of alternatives without standard insecticide applications.

In early September of each year of the study, a target number of 50 fruit per tree, chosen arbitrarily from a representative sample of all harvested fruit, was assessed for apple scab. Presence or absence of physiological maladies such as phytotoxicity (i.e., purple and cracked apple skin), russet, and lenticel blackening (dark discoloration surrounding the lenticels) were also recorded. For some trees with low fruit set, fewer than 50 fruit per tree were evaluated.

The harvest samples were also evaluated for arthropod damage. The presence of damage from the following insects was assessed: plum curculio; tarnished plant bug; apple maggot fly; stink bug (Hemiptera: Pentatomidae); European apple sawfly; internal Lepidoptera, which includes damage from codling moth, oriental fruit moth [Grapholita molesta (Busck)], and lesser appleworm [Grapholita prunivora (Walsh)]; and surface Lepidoptera.

Data obtained were subjected to analysis of variance and significant differences between means were determined by Fisher's protected least significant difference test $(P \leq$
0.05) (SAS Institute, 2002). When necessary, incidence data were transformed using the arcsine square root. In treatments with very low or no incidence for different variables, data could not be normalized and significance was determined by the non-parametric KruskalWallis test $(P \leq 0.05)$ (SAS Institute, 2002).

\section{Results}

In 2007, the SLS treatment provided effective management of apple scab with lesions evident on only $1.1 \%$ of the leaves in August and $0.4 \%$ of the fruit at harvest (Table $1)$. There were no significant differences among treatments in scab incidence on the cluster or terminal leaves in June. All of the alternative fungicides had significantly less foliar scab in August than the NTC but significantly more scab than the SLS treatment. On the fruit, the $\mathrm{PB}$ and $\mathrm{NO}$ treatments showed some activity against apple scab compared with the NTC trees; the percentages of fruit with scab at harvest were $11.2 \%$ and $11.6 \%$, respectively, both of which were less than the NTC and comparable to the SLS treatment.

Overall, the incidence of scab was much higher in 2008. The PB and Bs treatments had less scab on the cluster leaves in June than the NTC and were comparable to the SLS treatment (Table 1). On the terminal leaves in June, the SLS treatment had the lowest numerical incidence of scab, although it was not significantly different from incidence in the NO treatment. The NO treatment provided better management of apple scab than the NTC and the other alternatives based on evaluations of leaves in August and fruit at harvest. The PB treatment had less scab than the NTC but more than the NO-treated trees in August and at harvest. The SLS treatment had less scab than any of the other treatments with only $8.9 \%$ of the leaves in August and $2.9 \%$ of the fruit with lesions at harvest. Scab incidences on terminals and fruit in the Bs-treated trees were not different from those on the NTC trees.

The mite populations were much higher in 2007 than in 2008 (Table 2). In 2007, there were no differences among the treatments for either European red mites or two-spotted spider mites. In 2008, no difference was detected for European red mites among the treatments; however, there was a difference in the incidence of two-spotted spider mites with the SLS treatment having the highest incidence.

In 2007, there were no differences among treatments for any of the insect-related observations except that the Bs-treated trees had more leaves with potato leafhopper damage than the NTC (Table 3). In 2008, the only difference among treatments was in the incidence of white apple leafhoppers, with the Bs and PB treatments having more than the NTC trees although there was not a detectable difference in white apple leafhopper damage.

There was more plum curculio damage in June 2007 on the fruitlets in the Bs treatment than any other treatment, including the NTC (Table 3). There were no differences among the treatments in fruitlets damaged by tarnished plant bug or European apple sawfly. In June 2008 , there were no differences among treatments in the fruitlet assessment (Table 3). However, in both 2007 and 2008, the Bs treatment had the highest numerical incidence of plum curculio damage, although it was not

Table 2. Incidence of mites on 'Empire' terminal leaves, 2007 and 2008.

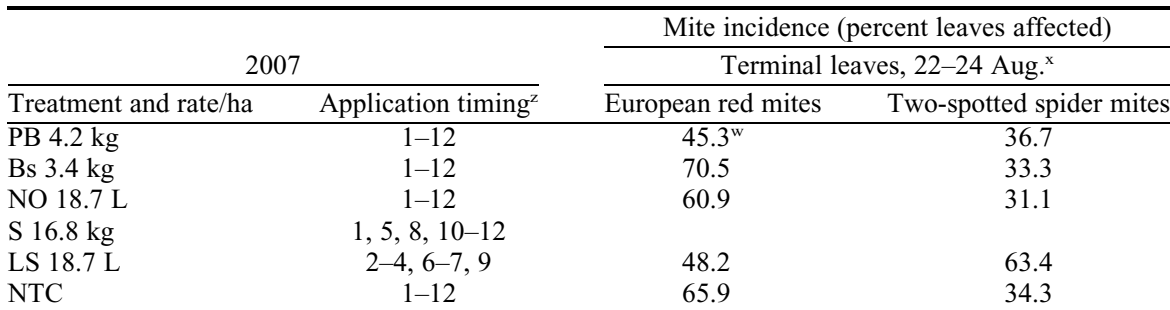

$1-12$

34.3

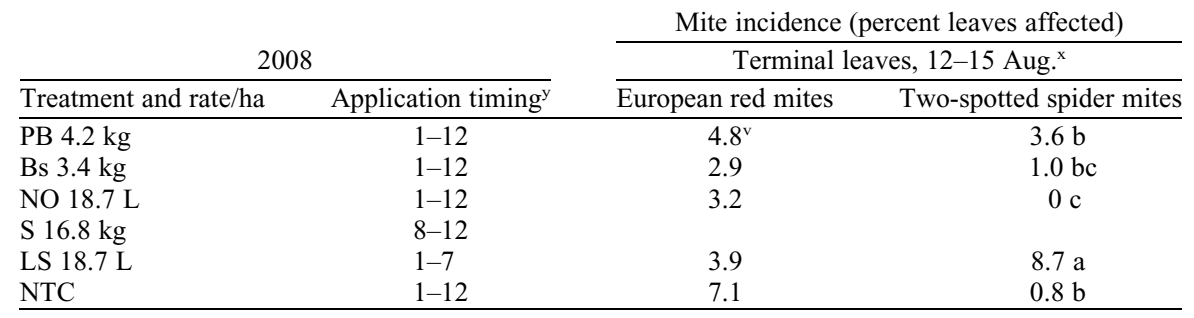

${ }^{\mathrm{z}}$ Application timings: $1=($ Green tip) 26 Apr.; $2=(\mathrm{TC}) 7$ May; $3=$ (Pink) 11 May; $4=$ (Pink) 17 May; $5=$ (Pink-Bloom) 24 May; $6=$ (Petal fall) 29 May; $7=7$ June; $8=14$ June; $9=22$ June; $10=29$ June; $11=12$ July; 12 = 23 July.

${ }^{y}$ Application timings: $1=$ (Green tip) 23 Apr.; $2=$ (TC) 1 May; $3=($ Pink) 7 May; $4=($ Bloom $) 14$ May; $5=$ (Petal fall) 21 May; $6=30$ May; $7=5$ June; $8=12$ June; $9=19$ June; $10=26$ June; $11=2$ July; $12=17$ July. ${ }^{\mathrm{x}}$ Assessment of 10 terminals per tree on five single-tree replicates per treatment.

${ }^{\text {w}}$ Columns with no letters following the numbers do not have a significant F-value, analysis of variance, $P \leq 0.05$ or Kruskal-Wallis, $P \leq 0.05$, when data normality could not be rescued with data transformation because of zeros in data.

"Numbers within columns followed by the same letter do not differ significantly, Kruskal-Wallis pairwise comparison, $P \leq 0.05$; the column with no letters following the numbers does not have a significant $\mathrm{F}$-value, analysis of variance, $P \leq 0.05$. 


\begin{tabular}{|c|c|c|c|c|c|c|c|c|}
\hline & & \multicolumn{7}{|c|}{ Insect pest incidence (percent leaves, fruitlets, or fruit affected) } \\
\hline & & \multicolumn{4}{|c|}{ Terminal leaves, 22-24 Aug. ${ }^{x}$} & \multirow{2}{*}{$\begin{array}{c}\text { Fruitlets, } 18-20 J^{\prime} e^{\mathrm{x}} \\
\begin{array}{c}\text { Plum curculio } \\
\text { damage }\end{array}\end{array}$} & \multicolumn{2}{|c|}{ Fruit, 10 Sept. $^{\mathrm{x}}$} \\
\hline $\begin{array}{l}\text { Treatment } \\
\text { and rate/ha }\end{array}$ & $\begin{array}{l}\text { Application } \\
\text { timing }^{\mathrm{z}}\end{array}$ & $\begin{array}{l}\text { White apple } \\
\text { leafhopper }\end{array}$ & $\begin{array}{l}\text { leafhopper } \\
\text { damage }\end{array}$ & $\begin{array}{c}\text { Potato } \\
\text { leafhopper }\end{array}$ & $\begin{array}{c}\text { Potato } \\
\text { leafhopper } \\
\text { damage }\end{array}$ & & $\begin{array}{c}\text { Plum curculio } \\
\text { damage }\end{array}$ & $\begin{array}{c}\text { Surface } \\
\text { Lepidoptera } \\
\text { damage }\end{array}$ \\
\hline$\overline{\mathrm{PB}} 4.2 \mathrm{~kg}$ & $1-12$ & $0.9^{\mathrm{w}}$ & 0 & 2.8 & $1.8 \mathrm{ab}$ & $2.0 \mathrm{~b}$ & 5.2 & 22.0 \\
\hline Bs $3.4 \mathrm{~kg}$ & $1-12$ & 0.7 & 0 & 3.4 & $3.0 \mathrm{a}$ & $9.2 \mathrm{a}$ & 8.4 & 26.4 \\
\hline NO $18.7 \mathrm{~L}$ & $1-12$ & 0.6 & 0 & 1.6 & $1.1 \mathrm{~b}$ & $1.0 \mathrm{~b}$ & 5.6 & 10.0 \\
\hline $\mathrm{S} 16.8 \mathrm{~kg}$ & $1,5,8,10-12$ & & & & & & & \\
\hline & & \multicolumn{7}{|c|}{ Insect pest incidence (percent leaves, fruitlets, or fruit affected) } \\
\hline \multirow{2}{*}{\multicolumn{2}{|c|}{2008}} & \multicolumn{4}{|c|}{ Terminal leaves, $12-15$ Aug. ${ }^{x}$} & ${\text { Fruitlets, } 16-18 \text { June }^{\mathrm{x}}}$ & \multicolumn{2}{|c|}{ Fruit, 3 Sept. $^{x}$} \\
\hline & & \multirow{2}{*}{\multicolumn{2}{|c|}{$\begin{array}{c}\text { White apple } \\
\text { leafhopper } \\
\text { damage }\end{array}$}} & \multirow[b]{2}{*}{$\begin{array}{c}\text { Potato } \\
\text { leafhopper }\end{array}$} & \multirow{2}{*}{$\begin{array}{c}\text { Potato } \\
\text { leafhopper } \\
\text { damage }\end{array}$} & \multirow[b]{2}{*}{$\begin{array}{l}\text { Plum curculio } \\
\text { damage }\end{array}$} & \multirow[b]{2}{*}{$\begin{array}{c}\text { Plum curculio } \\
\text { damage }\end{array}$} & \multirow{2}{*}{$\begin{array}{c}\text { Surface } \\
\text { Lepidopter } \\
\text { damage }\end{array}$} \\
\hline $\begin{array}{l}\text { Treatment } \\
\text { and rate/ha }\end{array}$ & $\begin{array}{c}\text { Application } \\
\text { timing }^{y}\end{array}$ & & & & & & & \\
\hline NTC & $1-12$ & $0.3 \mathrm{c}$ & 3.0 & 2.4 & 9.2 & 13.0 & $23.6 \mathrm{bc}$ & $40.0 \mathrm{bc}$ \\
\hline
\end{tabular}

${ }^{2}$ Application timings: 1 = (Green tip) 26 Apr.; $2=($ TC) 7 May; 3 = (Pink) 11 May; 4 = (Pink) 17 May; 5 = (Pink-Bloom) 24 May; $6=($ Petal fall) 29 May; 7 = 7 June; $8=14$ June; $9=22$ June; $10=29$ June; $11=12$ July; $12=23$ July.

${ }^{y}$ Application timings: 1 =(Green tip) 23 Apr.; $2=($ TC) 1 May; $3=($ Pink) 7 May; $4=($ Bloom $) 14$ May; $5=($ Petal fall) 21 May; $6=30$ May; $7=5$ June; $8=12$ June; $9=19$ June; $10=26$ June; $11=2$ July; $12=17$ July.

${ }^{\mathrm{x}}$ Assessment of 10 terminals, individual fruit on 10 fruit clusters, and 50 fruit per tree on five single-tree replicates per treatment.

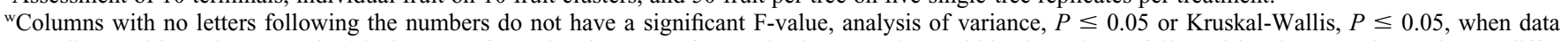
normality could not be rescued with data transformation because of zeros in data; numbers within the column followed by the same letter do not differ significantly, Fisher's protected least significant difference, $P \leq 0.05$.

'Numbers within the column followed by the same letter do not differ significantly, Kruskal-Wallis pairwise comparison, $P \leq 0.05$; columns with no letters following the numbers do not have a significant F-value, analysis of variance, $P \leq 0.05$ or Kruskal-Wallis, $P \leq 0.05$, when data normality could not be rescued with data transformation because of zeros in data.

"Numbers within the column followed by the same letter do not differ significantly, Fisher's protected least significant difference, $P \leq 0.05$.

Table 4. Incidence of foliage and fruit free of arthropod pests and their damage on 'Empire' trees, 2007 and 2008 .

\begin{tabular}{lccc}
\hline & \multicolumn{2}{c}{ Incidence free of arthropod and damage (percent leaves or fruit affected) } \\
\cline { 2 - 4 } Treatment & Terminal leaves & Fruit $^{\mathrm{z}}$ \\
\cline { 2 - 4 } and rate/ha & $50.7 \mathrm{~b}^{\mathrm{y}}$ & $52.8 \mathrm{~b}$ & 3 Sept. 2008 \\
\hline PB $4.2 \mathrm{~kg}$ & $51.1 \mathrm{ab}$ & $45.6 \mathrm{~b}$ & $19.6 \mathrm{~b}$ \\
Bs $3.4 \mathrm{~kg}$ & $60.3 \mathrm{a}$ & $77.1 \mathrm{a}$ & $20.0 \mathrm{~b}$ \\
NO $18.7 \mathrm{~L}$ & & & $37.6 \mathrm{a}$ \\
S $16.8 \mathrm{~kg}$ & $35.1 \mathrm{c}$ & $59.6 \mathrm{ab}$ & $17.5 \mathrm{~b}$ \\
LS 18.7 L & $55.8 \mathrm{ab}$ & $50.8 \mathrm{~b}$ & $26.0 \mathrm{~b}$ \\
NTC & &
\end{tabular}

${ }^{2}$ Assessment of 10 terminals, and 50 fruit per tree on five single-tree replicates per treatment.

'Numbers within the column followed by the same letter do not differ significantly, Fisher's protected least significant difference, $P \leq 0.05$.

statistically different from the other treatments in either year.

At the 2007 harvest, there were no differences among treatments in damage from plum curculio, tarnished plant bug, European apple sawfly, apple maggot fly, or internal and surface Lepidoptera species (Table 3). Results for 2008 were similar except that treatments affected the incidence of damage from plum curculio and surface Lepidoptera in 2008 (Table 3 ). The Bs-treated fruit had a higher incidence of plum curculio damage than the SLS, PB, and NTC fruit. The percent of fruit damage by surface Lepidoptera was higher in trees treated with PB or SLS than the NTC. There were no differences among the treatments for the incidence of stink bug damage in 2008 , the only year that data were collected (Table 3 ).

The percent of leaves free of all arthropod pests and their damage was assessed in 2008
(Table 4). The SLS treatment had the lowest percentage of leaves free of arthropods and their damage, having less than the NTC trees.

The NO treatment had significantly higher percentage of fruit free of insect damage than the other alternatives and the non-treated control in 2007 (Table 4). This was also seen in 2008 , in which the NO treatment had more fruit free of insect damage compared with other treatments.

There were no differences among the treatments in the incidence of the beneficial syrphid fly larvae, chrysopid eggs, cecidomyiid larvae, or lady bug insect populations in either year of the study, but the observed incidence never exceeded 1\% (data not shown).

In 2007, the SLS-treated fruit had phytotoxic burns (sunken, and often cracked, discolored skin) observed on $8.8 \%$ of the fruit, more than any of the other treatments (Table
5). There was also more russeting on fruit that received the SLS treatment. These burns and russeting reduced fruit quality. No fruit had phytotoxic burns in 2008; however, there was more russeting in the NO treatment than the other alternatives and the NTC (Table 5). The amount of russeting on NO-treated apples was not different from the SLS-treated apples. The Bs treatment resulted in an indirect phytotoxicity on the fruit with significantly more fruit with lenticel blackening \{which may be an early symptom of black rot [Botryosphaeria obtusa (Schwein) Shoemaker] \} than all other treatments in 2008 (Table 5). The NO treatment resulted in foliar phytotoxicity with more necrotic leaf spots than trees treated with Bs, SLS, and the NTC in 2007 and more than all other treatments in 2008 (Table 5).

\section{Discussion}

The overall incidence of scab was much higher in 2008, possibly because of two factors: 1) there was more overwintering inoculum, as indicated by a "high scab risk" rating in Fall 2007; and 2) there were more secondary infection periods as a result of the wet summer weather. In both years, the SLS treatment was the most effective against foliar scab at the end of each growing season and controlled fruit scab better than other treatments, except that the PB and NO treatments provided comparable levels of fruit scab control in 2007. In both years, the alternative treatments showed some activity against apple scab but did not provide acceptable control. 
Table 5. Phytotoxic effects of treatments on 'Empire' trees, 2007 and 2008.

\begin{tabular}{|c|c|c|c|c|c|}
\hline \multicolumn{2}{|c|}{2007} & \multicolumn{3}{|c|}{ Fruit, 10 Sept. $^{x}$} & \multirow{2}{*}{$\begin{array}{c}\text { Terminal leaves, 22-24 Aug. }{ }^{x} \\
\begin{array}{c}\text { Percent necrotic leaf } \\
\text { spot incidence }\end{array}\end{array}$} \\
\hline $\begin{array}{l}\text { Treatment } \\
\text { and rate/ha }\end{array}$ & $\begin{array}{l}\text { Application } \\
\text { timing }^{z}\end{array}$ & $\begin{array}{l}\text { Percent phytotoxic } \\
\text { burn incidence }^{\mathrm{w}}\end{array}$ & $\begin{array}{l}\text { Percent russet } \\
\text { incidence }\end{array}$ & $\begin{array}{c}\text { Percent lenticel } \\
\text { blackening incidence }\end{array}$ & \\
\hline$\overline{\mathrm{PB}} 4.2 \mathrm{~kg}$ & $1-12$ & $0 \mathrm{~b}^{\mathrm{t}}$ & $0.4 \mathrm{~b}$ & 0 & $35.3 \mathrm{a}$ \\
\hline Bs $3.4 \mathrm{~kg}$ & $1-12$ & $0 \mathrm{~b}$ & $0 \mathrm{~b}$ & 1.6 & $22.4 \mathrm{~b}$ \\
\hline NO $18.7 \mathrm{~L}$ & $1-12$ & $0 \mathrm{~b}$ & $0.4 \mathrm{~b}$ & 1.2 & $36.7 \mathrm{a}$ \\
\hline $\mathrm{S} 16.8 \mathrm{~kg}$ & $1,5,8,10-12$ & & & & \\
\hline LS $18.7 \mathrm{~L}$ & $2-4,6-7,9$ & $8.8 \mathrm{a}$ & $5.2 \mathrm{a}$ & 4.8 & $19.5 \mathrm{~b}$ \\
\hline NTC & $1-12$ & $0 \mathrm{~b}$ & $0.4 \mathrm{~b}$ & 0 & $16.9 \mathrm{~b}$ \\
\hline
\end{tabular}

\begin{tabular}{|c|c|c|c|c|c|}
\hline \multicolumn{2}{|c|}{2008} & \multicolumn{3}{|c|}{ Fruit, 3 Sept. $^{x}$} & \multirow{2}{*}{ 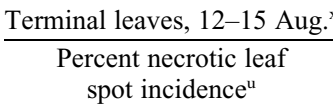 } \\
\hline $\begin{array}{l}\text { Treatment } \\
\text { and rate/ha }\end{array}$ & $\begin{array}{l}\text { Application } \\
\text { timing }^{\mathrm{y}}\end{array}$ & $\begin{array}{l}\text { Percent phytotoxic } \\
\text { burn incidence }^{\mathrm{w}}\end{array}$ & $\begin{array}{l}\text { Percent russet } \\
\text { incidence }\end{array}$ & $\begin{array}{c}\text { Percent lenticel } \\
\text { blackening incidence }\end{array}$ & \\
\hline$\overline{\mathrm{PB} 4.2 \mathrm{~kg}}$ & $1-12$ & $0^{\mathrm{s}}$ & $3.5 \mathrm{~b}$ & $6.1 \mathrm{~b}$ & $19.6 \mathrm{~b}$ \\
\hline Bs $3.4 \mathrm{~kg}$ & $1-12$ & 0 & $2.0 \mathrm{~b}$ & $12.4 \mathrm{a}$ & $15.8 \mathrm{bc}$ \\
\hline NO $18.7 \mathrm{~L}$ & $1-12$ & 0 & $8.8 \mathrm{a}$ & $5.2 \mathrm{bc}$ & $32.6 \mathrm{a}$ \\
\hline $\mathrm{S} 16.8 \mathrm{~kg}$ & $8-12$ & & & & \\
\hline LS $18.7 \mathrm{~L}$ & $1-7$ & 0 & $5.0 \mathrm{ab}$ & $0 \mathrm{c}$ & $11.9 \mathrm{c}$ \\
\hline NTC & $1-12$ & 0 & $1.2 \mathrm{~b}$ & $3.6 \mathrm{bc}$ & $18.1 \mathrm{~b}$ \\
\hline
\end{tabular}

${ }^{\mathrm{z} A p p l i c a t i o n}$ timings: $1=($ Green tip) 26 Apr.; $2=(\mathrm{TC}) 7$ May; $3=($ Pink) 11 May; $4=($ Pink $) 17$ May; $5=($ Pink-Bloom) 24 May; $6=($ Petal fall) 29 May; $7=7$ June; $8=14$ June; $9=22$ June; $10=29$ June; $11=12$ July; $12=23$ July.

${ }^{y}$ Application timings: $1=($ Green tip) 23 Apr.; $2=($ TC) 1 May; $3=($ Pink) 7 May; $4=($ Bloom $) 14$ May; $5=($ Petal fall $) 21$ May; $6=30$ May; $7=5$ June; $8=12$ June; $9=19$ June; $10=26$ June; $11=2$ July; $12=17$ July.

${ }^{\mathrm{x}}$ Assessment of 50 fruit, and 10 terminals per tree on five single-tree replicates per treatment.

w Phytotoxic burn = cracked, often sunken, discolored skin.

${ }^{\mathrm{v} L e n t i c e l ~ b l a c k e n i n g}=$ black discoloration around lenticels on skin; possible early symptom of black rot [Botryosphaeria obtusa (Schwein) Shoemaker].

"Necrotic leaf spot = non-specific, unidentified necrotic leaf spots.

'Numbers within columns followed by the same letter do not differ significantly, Kruskal-Wallis pairwise comparison, $P \leq 0.05$; columns with no letters following the numbers do not have a significant F-value, analysis of variance, $P \leq 0.05$ or Kruskal-Wallis, $P \leq 0.05$, when data normality could not be rescued with data transformation because of zeros in data.

${ }^{\mathrm{s}}$ Numbers within columns followed by the same letter do not differ significantly, Fisher's protected least significant difference, $P \leq 0.05$.

In 2008, the NO and PB treatments resulted in less fruit scab at the end of the growing season than the Bs treatment with the latter being no better than the NTC.

Although potassium bicarbonate showed activity against apple scab under Vermont conditions, it was not as effective as the sulfur/ lime sulfur treatment, which is similar to results of previous studies (Jamar et al., 2008, 2010; Jamar and Lateur, 2007; Tamm et al., 2006). Tamm et al. (2006), in a study in Switzerland, showed potassium bicarbonate-controlled apple scab as well as a wettable sulfur treatment. A study in Belgium showed a potassium bicarbonate treatment resulted in significantly less foliar and fruit scab than a water control and provided scab control comparable to a wettable elemental sulfur treatment (Jamar et al., 2008). However, sulfur is a less effective scab fungicide compared with lime sulfur, therefore indicating potassium bicarbonate has some activity but could not successfully be used alone in a fungicide program. In a second Belgium study, a potassium bicarbonate treatment significantly reduced apple scab incidence and severity on fruit compared with water control treatments (Jamar and Lateur, 2007). The results of this Vermont study similarly show potassium bicarbonate was better than no fungicide treatment but was not the most effective option for apple scab management. Under the conditions of a study conducted in Pennsylvania, a potassium bicarbonate program was comparable to a sulfur/lime sulfur program for the management of apple scab in an organic alternative fungicide trial (Travis et al., 2005). This greater effectiveness of potassium bicarbonate could be attributed to reduced disease pressure and/or fungicide application timing in relation to infection periods.

Apparently no studies examining the effects of neem oil against apple scab have been published. Moline and Locke (1993) showed neem oil had some fungicidal activity toward select postharvest apple decay fungi such as Botrytis cinera (pers.) ex Fr. (gray mold) and Glomerella cingulata (Ston.) Spauld. \& Schrenk. (bitter rot) but was not effective against Penicillium expansum Thom. (blue mold rot). As part of a broader assessment of sulfur/lime sulfur and alternative fungicides against other apple diseases, Cromwell et al. (2009) evaluated fruit rots at harvest and found no differences between the neem oil treatment and the other treatments, including the nontreated control, in either year.

The research from this Vermont study verifies past research showing that Bacillus subtilis does not provide suitable management of apple scab (Palm et al., 2002; Travis et al., 2005; Yoder et al., 2005). Furthermore, data from this study show that applications of Bs can have adverse, non-target impacts in that it exacerbated plum curculio damage in both years and potato leafhopper damage in 2007. In addition, the fruit from Bs-treated trees had significantly more lenticel blackening than trees treated with SLS, PB, or NO and NTC trees. Further research is necessary to provide insight into the reasons for these results.

Overall, none of the alternatives evaluated in this study were as effective for controlling apple scab as the standard SLS fungicide program. In 2008, the NO treatment performed better than the other alternatives in management of foliar and fruit scab in August and September, respectively. The NO treatment had significantly more fruit without insect damage at harvest than the other alternatives and the NTC in 2007 and more than all treatments in 2008. This beneficial non-target effect can be attributed to the insecticidal properties of neem oil. Neem oil (Trilogy) is marketed as a fungicide/insecticide/miticide so it was expected to suppress insects. Percentages of fruit free of insect damage were higher in 2007 presumably because additional insecticide applications of Bacillus thuringiensis (Dipel DF) and spinosad (Entrust) were used in 2007, whereas only kaolin clay (Surround WP) was applied in 2008. However, with no other insecticides used in 2008, the insect management from the NO treatment was not commercially acceptable. Although these results suggest that neem oil alone is not an effective insect management program in apples, the change in insecticide protocol from 2007 to 2008 means further studies are needed to confirm these non-target effects.

Both the SLS and NO treatments had disadvantages such as phytotoxic burning and/ or russeting of the fruit. The burns observed in 2007 on the SLS-treated fruit may have been caused by the high rate of lime sulfur $(2 \%)$ applied 7 June 2007 when the next day's temperatures reached $32.1^{\circ} \mathrm{C}$. However, similar hot temperatures followed lime sulfur applications in 2008, and no phytotoxic effects resulted, which suggests a combination of conditions such as slow drying and high humidity may have caused the injury in 2007. Past research in New York has found summer sprays of lime sulfur can cause injury to both fruit and foliage (Gloyer, 1933). Using a reduced rate of lime sulfur, or a sulfur application, could have potentially reduced the phytotoxicity, 
but might also have reduced the effectiveness of disease management.

The NO treatment also caused non-specific, unidentified necrotic leaf spots. This apparent phytotoxic effect is potentially the result of the oil-based formulation of the clarified hydrophobic extract of neem oil. Agnello et al. (1994) found horticultural oils applied for mite control under conditions of high temperature and moisture stress caused foliar lesions, mainly in the portions of the canopy where the spray had dried unevenly or had accumulated; the incidence and severity of the lesions increased when higher concentrations of oil were applied.

The assessment of mites in this study supported the findings of several other studies (Holdsworth, 1972; MacPhee and Sanford, 1954, 1956; van de Vrie, 1962) in that elemental sulfur- and lime sulfur-based fungicides can have adverse affects on mite management. Although no significant differences were detected in the European red mite population among the treatments, the two-spotted spider mites were numerically higher in the SLS treatment than all the other treatments in 2007 and significantly higher in 2008. In addition, the SLS treatment had the lowest percent of leaves free of arthropods and their damage, lower than all three alternatives and the NTC, confirming the increased mite populations. Because predatory mite populations were not assessed in this experiment, no assumptions can be made as to why there were differences in two-spotted spider mite populations among treatments.

This research shows that potassium bicarbonate, Bacillus subtilis, and neem oil do not offer an advantage over the standard sulfur/ lime sulfur fungicide program in organic apple production in Vermont. The Bacillus subtilis alternative appears to have negative impacts on management of some pest populations and causes lenticular blackening on the fruit. The clarified hydrophobic extract of neem oil applied on a fungicide schedule is not sufficient to control pest insects. Foliar and fruit phytotoxicity was a consistent problem for the standard sulfur/lime sulfur fungicide program as well as for these alternative materials. Overall, these non-target effects of the alternative materials are a significant disadvantage.

\section{Literature Cited}

Agnello, A.M., W.H. Reissig, and T. Harris. 1994. Management of summer populations of European red mite (Acari: Tetranychidae) on apple with horticultural oil. J. Hort. Entomol. 87: 148-161.

Burrell, A.B. 1945. Practical use of our newer knowledge of apple scab control. Proc. of New York State Hort. Soc. 90:9-16.

Cooley, D.R., L.M. Los, G. Hamilton, A.T. Eaton, L.P. Berkett, T.L. Bradshaw, H.H. Faubert, G. Koehler, R. Moran, R. Spitko, and G. Morin. 2008. 2008 New England Tree Fruit Mgt. Guide. USDA Coop. Ext. Serv., Univ. of Connecticut, New Hampshire, Maine, Rhode Island, Massachusetts, and Vermont.

Cromwell, M.L., L.P. Berkett, T. Ashikaga, H.M. Darby, T. Bradshaw, and S. Kingsley-Richards. 2008. Evaluation of alternative fungicides for organic apple production in Vermont, 2007. Plant Dis. Mgt. Rpt. 2:PF048.

Cromwell, M.L., L.P. Berkett, H.M. Darby, and T. Ashikaga. 2009. Evaluation of alternative fungicides for organic apple production in Vermont. MS thesis, Univ. of Vermont, Burlington, VT.

Díaz Arias, M.M., J.C. Batzer, T.C. Harrington, A.W. Wong, S.C. Bost, D.R. Cooley, M.A. Ellis, J.R. Hartman, D.A. Rosenberger, G.W. Sundin, T.B. Sutton, J.W. Travis, M.J. Wheeler, K.S. Yoder, and M.L. Gleason. 2010. Diversity and biogeography of sooty blotch and flyspeck fungi on apple in the eastern and midwestern United States. Phytopathology 100:345-355.

Ellis, M.A., D.C. Ferree, R.C. Funt, and L.V. Madden. 1998. Effects of an apple scabresistant cultivar on use patterns of inorganic and organic fungicides and economics of disease control. Plant Dis. 82:428-433.

Environmental Protection Agency. 2006. Toxicity categories and pesticide label statements. $<\mathrm{http}: /$ www.epa.gov/pesticides/health/tox_categories. $h \mathrm{tm}>$.

Gadoury, D.M. and W.E. MacHardy. 1982. A model to estimate the maturity of ascospores of Venturia inaequalis. Phytopathology 72:901904.

Gadoury, D.M., A. Stensvand, and R.C. Seem. 1998. Influence of light, relative humidity, and maturity of populations on discharge of ascospores of Venturia inaequalis. Phytopathology 88:902-909.

Gloyer, W.O. 1933. Evaluation of applications of lime-sulfur for the control of apple scab. New York State Agr. Expt. Station, Geneva, NY. Bul. No. 624. p. 2-39.

Hamilton, J.M. and G.W. Keitt. 1928. Certain sulfur fungicides in the control of apple scab. Phytopathology 18:146-147.

Holb, I.J., P.F. De Jong, and B. Heijne. 2003. Efficacy and phytotoxicity of lime sulfur in organic apple production. Ann. Appl. Biol. 142:225-233.

Holdsworth, R.P. 1972. European red mite and its major predators: Effects of sulfur. J. Econ. Entomol. 65:1098-1099.

Jamar, L., M. Cavelier, and M. Lateur. 2010 Primary scab control using a "during-infection" spray timing and the effect on fruit quality and yield in organic apple production. Biotechnol. Agron. Soc. Environ. 14:423-439.

Jamar, L. and M. Lateur. 2007. Strategies to reduce copper use in organic apple production, ISHS. Acta Hort. 737:113-120.

Jamar, L., B. Lefrancq, C. Fassotte, and M. Lateur. 2008. A during-infection spray strategy using sulphur compounds, copper, silicon and a new formulation of potassium bicarbonate for primary scab control in organic apple production. Eur. J. Plant Pathol. 122:481-493.

Jones, A.L. and H.S. Aldwinckle. 1990. Compendium of apple and pear diseases. APS Press, The Amer. Phytopathol. Soc., St. Paul, MN.

Lewis, F.H. and K.D. Hickey. 1972. Fungicide usage on deciduous fruit trees. Annu. Rev. Phytopathol. 10:399-428.

MacDaniels, L.H. and J.R. Furr. 1930. The effect of dusting-sulfur upon the germination of the pollen and the set of the fruit of the apple. Cornell Univ. Agr. Expt. Sta. Bul. 499:1-13.

MacHardy, W.E. 1996. Apple scab biology, epidemiology and management. The Amer. Phytopathol. Soc. Press, St. Paul, MN.

MacHardy, W.E. and D.M. Gadoury. 1989. A revision of Mill's criteria for predicting apple scab infection periods. Phytopathology 79: 304-310.
MacPhee, A.W. and K.H. Sanford. 1954. The influence of spray programs on the fauna of apple orchards in Nova Scotia. VII. Effects on some beneficial arthropods. The Can. Entomologist 86:128-135.

MacPhee, A.W. and K.H. Sanford. 1956. The influence of spray programs on the fauna of apple orchards in Nova Scotia. X. Supplement to VII. Effects on some beneficial arthropods. The Can. Entomologist 88:631-634.

McArtney, S., J. Palmer, S. Davies, and S. Seymour. 2006. Effects of lime sulfur and fish oil on pollen tube growth, leaf photosynthesis and fruit set in apple. HortScience 41:357-360.

Mitre, I., V. Mitre, R. Sestras, A. Pop, and A. Sestras. 2009. Potassium bicarbonate in preventing and control of apple scab. Bul. Univ. Agr. Sci. Vet. Med. Cly-Napoca Hort. 66: 186-190.

Mitre, V., I. Mitre, A.F. Sestras, and R.E. Sestras. 2010. New products against apple scab and powdery mildew attack in organic apple production. Not. Bot. Hort. Agrobot. Cluj 38: 234-238.

Moline, H.E. and J.C. Locke. 1993. Comparing neem seed oil with calcium chloride and fungicides for controlling postharvest apple decay. HortScience 28:719-720.

Palm, G., K. Klopp, and P. Kruse. 2002. Control of scab: Substitutes for and minimal use of copper, p. 75-80. Proc. 10th Intl. Conf. on Cultivation Technique and Phytopath. Problems in Organic Fruit Growing and Viticulture, Weinsberg, Germany.

Palmer, J.W., S.B. Davies, P. Shaw, and J.N. Wunsche. 2003. Growth and fruit quality of 'Braeburn' apple trees as influenced by fungicide programmes suitable for organic production. N. Z. J. Crop Hort. Sci. 31:169-177.

Palmiter, D.H. and R.M. Smock. 1954. Effect of fungicides on McIntosh apple yield and quality: A five year study under Hudson Valley conditions 1949-1953. New York State Agr. Expt Sta., Geneva, NY.

Reardon, J.E., L.P. Berkett, M.E. Garcia, A. Gotlieb, T. Ashikaga, and G. Badger. 2005. Field evaluation of the new sequential sampling technique for determining apple scab "risk." Plant Dis. $89: 228-236$.

SAS Institute. 2002. SAS Institute Inc., Cary, NC

Stensvand, A., D.M. Gadoury, T. Amundsen, L. Semb, and R.C. Seem. 1997. Ascospore release and infection of apple leaves by conidia and ascospores of Venturia inaequalis at low temperatures. Phytopathology 87:1046-1053.

Tamm, L., T. Amsler, H. Scharer, and M. Refardt. 2006. Efficacy of Armicarb (potassium bicarbonate) against scab and sooty blotch on apples. Proc. of 12th International Conference on Cultivation Technique and Phytopathological Problems in Organic Fruit-Growing Jan. 31-2 Feb. 2006. Intl. Federation of Organic Agr, Movements.

Travis, J.W., N.O. Halbrendt, J. Rytter, B. Lehnam, and B. Jarjour. 2005. Evaluation of organic alternatives for control of apple scab, 2005. Biological and Cultural Tests 21:N009.

van de Vrie, M. 1962. The influence of spray chemicals on predatory and phytophagous mites on apple trees in laboratory and field trials in The Netherlands. BioControl 7:243250 .

Yoder, K.S., A.E. Cochran II, W.S. Royston Jr., and S.W. Kilmer. 2005. Fungal disease control by organic and biocontrols on Jonagold apple, 2005. Fungicide and Nematicide Tests 61: PF016. 